https://doi.org/10.48009/1_iis_2006_226-230

\title{
FACTORS INFLUENCING MAJOR SELECTION BY COLLEGE OF BUSINESS STUDENTS
}

\author{
William J. Crampton, Illinois State University, wjcramp@ilstu.edu \\ Kent A. Walstrom, Illinois State University, kawalst@ilstu.edu \\ Thomas P. Schambach, Illinois State University, tpscham@ilstu.edu
}

\begin{abstract}
The purpose of this study was to examine some of the factors that influence and impact business students when they select their major. Factors related to familiarity with possible career options and sources of information were examined. In addition, traditional factors, such as those related to career outcomes, characteristics of the profession itself, and referent groups, were also examined. Respondents were more knowledgeable about careers in management, marketing, accounting, and finance than they were about careers in other areas. Awareness of opportunities in information systems careers ranked particularly low. While the most significant sources of information used when selecting a major were not clearly identified in the findings of this study, the television or movie portrayal of the occupation, the information on the college/department web site, brochures about the major, newspaper articles and information on the Internet/web were ranked the most important from the list provided. Factors related to the profession itself, such as personal interest in the subject matter, long-term salary prospects, probability of working in the field after graduation, starting salary, and prestige of the profession, had great importance when selecting a major. However, student perceptions of various profession-related attributes may not align with reality.
\end{abstract}

Keywords: Academic Choice, Career Choice, Information Systems Education, Student Awareness, Student Interest

\section{INTRODUCTION}

Recently, there has been much discussion regarding the demise of the American technology worker [5] and, particularly, workers in the information technology profession [2]. After the boom times of the late 1990s, the job market for IT workers eroded during the economic recession of the early $21^{\text {st }}$ Century. Economy related job loss in combination with the increase in IT outsourcing led some to proclaim the IT profession doomed to decline within the USA. Despite headline news articles, the overall job market for IS professionals has remained relatively strong and, according to U.S. Bureau of Labor Statistics projections, remains one of the major occupational growth areas for the next decade [9]. Yet, it is possible new college students and their advisors have been swayed by the gloomy headlines; for certainly, enrollment has plunged in most college computer science and information systems programs [4]. With job growth expected, and enrollments in information technology related majors near an all time low, it is in our nation's best interest to better understand the phenomenon of degree major selection by students at our institutions of higher learning. Historically, enrollment trends in different areas of study oscillate and interest in differing college of business degree programs fluctuate. Currently, enrollments in information systems related degrees are very low. Similarly, in the late 1990s, enrollment in accounting degree programs was down. Consequently, there is now an insufficient supply of properly schooled accounting graduates and that labor market is very tight. Fortunately, the excessively tight job market for accountants is now drawing large numbers of students to that discipline. Nonetheless, it would be helpful to attract students to a discipline before a labor shortage becomes obvious. While student career choice patterns are likely to vary over time, it would be beneficial to both the students and society if we can ensure new entrants are making informed choices about life-influencing career and degree decisions. Can we influence, impact or predict these fluctuations? The purpose of this study was to examine some of the factors that influence and impact business students when they select their major. Factors related to familiarity with possible career options and sources of information were examined. In addition, traditional factors, such as those related to career outcomes, characteristics of the profession itself, and referent groups, were also examined.

\section{LITERATURE REVIEW}

Until recently, information technology related majors have enjoyed an abundance of student enrollments. Therefore, little attention has been given to understanding why students select these majors. 
Correspondingly, little research has been published documenting the factors that influence student selection of information systems and technology majors. Instead, we will have to examine previous studies done in other disciplines. We will first review studies done on the accounting major and conclude with a review of career/occupational choice studies that have been conducted without focusing on a single academic major.

Recently, a number of studies have been conducted examining the selection of accounting as a major. In the late 1990s, the accounting field experienced drastic declines in the number of majors spurring concern about the perilous future of the profession [1]. Twenty-one separate studies of the choice-ofmajor decision were reviewed by Simons, et al. [13]. They identified the principal categories in student expectations when selecting a major as: earnings, career opportunities, career characteristics, and characteristics of the major. They found the most important career factors when selecting a major were: financial rewards (with long-term earnings outweighing initial earnings), job availability, and interest in the major/career.

After surveying professors and accounting practitioners, Albrecht and Sack [1] enumerated five major reasons for declining enrollments in accounting programs. The reasons given included 1) starting salaries that were low relative to other business majors, 2) students having more attractive career alternatives than in the past, 3) contemporary students more willing to choose risky majors than in the past, 4) a lack of information and considerable misinformation about what accountants do, and 5) concern that the 150-hour rule increased the effort and the opportunity cost associated with majoring in accounting. In an effort to evaluate these findings Francisco, et al. [6] found the major reasons for not majoring in accounting included "quality of work" issues (accounting viewed as boring), and their research also supported the conclusion that misinformation and misconceptions about what accountants do are pervasively held by high school teachers, counselors, and students.

Noland, et al., [12] found the factors influencing major selection by accounting and information systems majors were long-term salary possibilities, prestige of the profession, job security, and starting salary, while influence of a professor, influence of family members, and difficulty of the subject matter rated much lower. Alumni, the Internet, newspapers, and TV were rated as the top information sources influencing the choice of major. The researchers also suggested that high school teachers have a stronger influence on the major choice of African American students, and that females are under-represented in the information systems major. John-Charles and Walstrom [10] found the primary reasons that African American students selected their major were interest and enjoyment in an area of study, enjoyment of the working conditions, and marketability.

Ultimately, declining enrollments in accounting were reversed, perhaps related to lessons learned through research, albeit many would credit the Sarbanes Oxley Act of 2002 that brought abundant attention to the accounting profession and was dubbed 'the full employment act for accountants.'

Galotti and Kozberg [8] listed the following four factors as the most important in influencing students when selecting a major in general: "How much I care about the subject," "Something I do well in," "Something with good career opportunities," and "What I want to do with this major after college." In a subsequent study, Galotti [7] found that students relied on only a few criteria as part of their academic choice decision. While students acknowledged the importance of the choice of major decision, they found the decision process stressful and reduced their stress by restricting the number of alternatives and criteria they considered. These criteria were grouped into several categories. The top six categories were: interest/enjoyment, ability, values, curriculum requirements, departmental reputation, and parental advice.

Lowe and Simons [11] studied the relative importance of 13 factors influencing the choice of business major. They found that the most important criteria influencing the choice of major across all business student majors were: future earnings, career options, initial earnings, and ability/aptitude. Moreover, they found distinguishable differences among majors. For example, accounting students were particularly influenced by external factors such as long term earnings, initial earnings and career options; whereas, marketing majors highlighted interesting subject matter, and management majors rated self-employment opportunities highly. For all groups studied, referents sources (parents, teachers) had only moderate influence on the major selected.

\section{METHODOLOGY}

A questionnaire was constructed and administered to students enrolled in an introductory business course designed for incoming freshman at this large midwestern university (USA). The questionnaire closely 
corresponds to the instrument used in Noland, et al. [12]. The purpose of the course is to introduce freshman business students to the theory and practice of private enterprise, including purposes, structures, functional areas and related institutions. The course is also intended to ensure students are making an informed career choice decision by having them research and be exposed to career information in various business disciplines. Participation in the survey was voluntary and the confidentiality of individual responses was assured.

\section{FINDINGS}

A total of 89 responses were collected from three different classes taught by three different instructors of the same introductory business course. Of the 89 responses, 32 were female and 57 were male. This suggests an under-representation of females in these course sections since the overall university population is about $55 \%$ female. Forty-eight of the respondents were 17-18 years old, thirty-seven were 19-20 years old, three were 21-22 years old and one was over 25 . Thus, virtually all of the students would be classified as 'traditional' age college students. Eighty-five of the respondents were white, three were African American and one was Hispanic. Again, this suggests an under-representation of minority students relative to the university (and College of Business) at large. Seventy-seven of the respondents reported being freshman, seven were sophomores and five were juniors.

Using a 6-point Likert-type scale, students were asked to reflect or indicate their level of awareness of career opportunities in various business disciplines when they completed high school. Table 1 shows that, coming out of high school, respondents were most knowledgeable about possible careers in management, marketing, accounting and finance. They were least knowledgeable about possible careers in computer science, information systems, and logistics/operations.

Table 2 shows the importance of different information sources in helping respondents select their major. Interestingly, none of the information sources listed were considered very important. On a scale of 1-6, 3.50 is the midpoint and none of the information sources, on average, scored above the midpoint. Somewhat surprisingly, the highest ranked information source is the television or movie portrayal of the occupation.
Table 1. Responses to the Question: How knowledgeable and informed (aware) were you about possible careers in each of the following areas when you completed high school? (in order from most to least knowledgeable)

\begin{tabular}{|l|c|}
\hline Area & $\begin{array}{l}\text { Mean Reported Career } \\
\text { Knowledge Level* }\end{array}$ \\
\hline Management & 4.17 \\
\hline Marketing & 3.97 \\
\hline Accounting & 3.66 \\
\hline Finance & 3.62 \\
\hline Insurance & 3.44 \\
\hline Economics & 3.27 \\
\hline International Bus & 3.27 \\
\hline Computer Science & 2.87 \\
\hline Information Systems & 2.83 \\
\hline Logistics/Operations & 2.35 \\
\hline
\end{tabular}

* 1 = Not Aware; 6 = Excellently Informed

Table 2. Importance of Information Sources When Respondents Select Their Major (in order of importance from most to least)

\begin{tabular}{|l|c|}
\hline \multicolumn{1}{|c|}{ Information Source } & \multicolumn{1}{c|}{$\begin{array}{c}\text { Average } \\
\text { Importance* }\end{array}$} \\
\hline $\begin{array}{l}\text { Television or Movie Portrayal of } \\
\text { the Occupation }\end{array}$ & 3.27 \\
\hline $\begin{array}{l}\text { Information on } \\
\text { College/Department Website }\end{array}$ & 3.19 \\
\hline Brochures About the Major & 3.15 \\
\hline Newspaper Articles & 3.12 \\
\hline Information on Internet/Web & 3.11 \\
\hline Online Job Listing(s) & 2.85 \\
\hline Presentations by Faculty & 2.79 \\
\hline Job Listings in Classified Ads & 2.70 \\
\hline $\begin{array}{l}\text { Presentations by Current } \\
\text { Students }\end{array}$ & 2.64 \\
\hline Presentations by Alumni & 2.57 \\
\hline Invited Speakers & 2.54 \\
\hline Informational CDs or DVDs & 2.21 \\
\hline
\end{tabular}

* 1 = Not Important; 6 = Very Important

Of the information sources listed, the sources of highest importance were television or movie portrayal of the occupation, information on college/department web site, brochures about the major, newspaper articles and information on Internet/web. Presentations by faculty, current students, alumni or invited speakers were all rated very low, as were informational CDs or DVDs. While we might not want to admit it, it does appear that this is the MTV generation. They are more 
deeply influenced by television than we would like. However, this is consistent with how many imagine the way in which high school students spend their free time. That is, watching television and movies, emailing and surfing the Internet. These activities are commonly viewed as occupying a large number of hours and may represent a major component of students' social contact but may also generate or reinforce whimsical stereotypes that inaccurately depict reality. Brousseau and Driver [3, p. 25] argued that: "Chief among the factors that appear to cause poor job choices ... are fanciful stereotypes that depict opportunity and reality inaccurately."

Table 3 shows the importance of other factors impacting respondent selection of a major. This table is composed mostly of career factors and personal referent sources. The most important factors were career oriented: personal interest in the subject matter, long-term salary prospects, and probability of working in the field after graduation. These were followed closely in importance by: starting salary, prestige of profession, job security of related occupations and occupational growth forecasts/predictions. The factors rated as the least important were referent sources: high school guidance counselor(s), university career services program(s), and university advisement center. 'Family member' is the only referent source that, on average, scored above the midpoint of the 6-point rating scale.

The top nine factors are related to career outcomes and characteristics of the profession itself. Factors related to high school, university and friends and family all ranked well behind in importance to the profession itself.
Table 3. Importance of Factors in "Why" Respondents Selected their Major (in order of importance from most to least)

\begin{tabular}{|c|c|}
\hline Factor & $\begin{array}{c}\text { Average } \\
\text { Importance* }\end{array}$ \\
\hline $\begin{array}{l}\text { Personal Interest in Subject } \\
\text { Matter }\end{array}$ & 5.03 \\
\hline Long-Term Salary Prospects & 5.03 \\
\hline $\begin{array}{l}\text { Probability of Working in Field } \\
\text { After Graduation }\end{array}$ & 4.80 \\
\hline Starting Salary & 4.48 \\
\hline Prestige of Profession & 4.47 \\
\hline $\begin{array}{l}\text { Job Security of Related } \\
\text { Occupations }\end{array}$ & 4.35 \\
\hline $\begin{array}{l}\text { Occupational Growth } \\
\text { Forecasts/Predictions }\end{array}$ & 4.33 \\
\hline $\begin{array}{l}\text { Ease of Subject Matter - Easy } \\
\text { for Me }\end{array}$ & 4.15 \\
\hline $\begin{array}{l}\text { Opportunities for Ongoing } \\
\text { Professional Development }\end{array}$ & 4.11 \\
\hline $\begin{array}{l}\text { Performance in High School } \\
\text { Subject Matter Courses }\end{array}$ & 3.93 \\
\hline $\begin{array}{l}\text { Reputation of Degree Program at } \\
\text { University }\end{array}$ & 3.92 \\
\hline Family Member(s) & 3.75 \\
\hline $\begin{array}{l}\text { Reputation of University Degree } \\
\text { Program Faculty }\end{array}$ & 3.72 \\
\hline $\begin{array}{l}\text { Performance in University } \\
\text { Subject Matter Courses }\end{array}$ & 3.49 \\
\hline $\begin{array}{l}\text { Probability of Graduating with } \\
\text { Honors in Major }\end{array}$ & 3.47 \\
\hline Flexibility of Work Schedule & 3.44 \\
\hline $\begin{array}{l}\text { Difficulty of Subject Matter - } \\
\text { Difficult for Most People }\end{array}$ & 3.39 \\
\hline Professor(s) at University & 3.28 \\
\hline High School Teacher(s) & 3.17 \\
\hline $\begin{array}{l}\text { High School Career/Interest } \\
\text { Tests/Assessments }\end{array}$ & 3.09 \\
\hline Friend(s) & 3.01 \\
\hline University Advisor(s) & 2.94 \\
\hline $\begin{array}{l}\text { Opportunity to Participate in } \\
\text { Student Organizations }\end{array}$ & 2.80 \\
\hline $\begin{array}{l}\text { Counseling Center } \\
\text { Career/Interest } \\
\text { Tests/Assessments }\end{array}$ & 2.78 \\
\hline $\begin{array}{l}\text { High School Guidance } \\
\text { Counselor(s) }\end{array}$ & 2.64 \\
\hline $\begin{array}{l}\text { University Career Services } \\
\text { Program(s) }\end{array}$ & 2.58 \\
\hline University Advisement Center & 2.47 \\
\hline
\end{tabular}

* 1 = Not Important; 6 = Very Important 


\section{CONCLUSIONS}

Upon completion of high school, respondents indicated that they were most knowledgeable about careers in management, marketing, accounting, and finance and least knowledgeable about information systems, computer science and logistics/operations. Since the respondents were mostly unaware of these occupations, this suggests the choice of computing related majors is not even being considered by students when they graduate from high school. While these respondents are members of a generation known for its pervasive use of technology, computers and computer-enabled devices, it appears they have little awareness of, or interest in, the occupations that are driving the digital age.

This study failed to identify the important sources of information used by students when selecting their major. Of the information sources listed, the television or movie portrayal of the occupation, the information on the college/department web site, brochures about the major, newspaper articles and information on the Internet/web were most important. However, as noted earlier, these sources were all rated below 3.50 (the midpoint) making them less than average importance. While the college/department web site was ranked relatively high, it is unlikely students will visit the department website for computing related majors unless they become more aware that these are potentially rewarding career areas. In the absence of TV/movies glamorizing these fields, it is unlikely prospective students will seek related information sources.

Factors related to the profession itself had a greater importance when selecting a major than factors related to the university programs in that profession, the influence of high school advisors or counselors, or the influence of university advisers or counselors. Admittedly, since most respondents were freshman, the university advisors had limited chances to influence these respondents. Nonetheless, it appears these students are not receiving, or are ignoring, the career information and advice they should have received in high school. Unfortunately, the low influence of referents is not unique to this study. Given the growth rate of IT related jobs and the dependence of the national economy on a strong technological foundation, it is imperative that academic institutions discover a way to better inform students of a wide variety of occupational choices. To this end, more studies are needed in order to learn how to best communicate with and inform contemporary students of apparently undiscovered IT related career opportunities.

\section{REFERENCES}

1. Albrecht, W. S., \& Sack, R. J. (2000). Accounting education: Charting the course through a perilous future. Accounting Education Series, 16, Sarasota, FL: Am Acctg Assoc.

2. Baker, S., \& Kripalani, M. (2004). Software: Will outsourcing hurt America's supremacy? Business Week, March 1, 84-95.

3. Brousseau, K. R., \& Driver, M. J. (1994). Enhancing informed choice: A career-concepts approach to career advisement. Selections, 10(3), 24-31.

4. Chabrow, E. (2004). By The Book: Declining computer-science enrollments should worry anyone interested in the future of the U.S. IT industry. Information Week, (August 16), 36-46.

5. Engardio, P., Bernstein, A., \& Kripalani, M. (2003). Is your JOB next? Business Week, February 3, 50-60.

6. Francisco, W.H., Noland, T. G., \& J.A. Kelly (2003). Why don't students major in accounting? Southern Business Review, 29(1), 37-40.

7. Galotti, K.M. (1999). Making a "major" real-life decision: college students choosing an academic major. Journal of Educational Psychology, 91(2), 379-387.

8. Galotti, K.M. \& Kozberg, S.F. (1987). Older adolescents' thinking about academic/vocational and interpersonal commitments. Journal of Youth and Adolescence, (16), 313-330.

9. Hecker, D. E. (2005). Occupational employment projections to 2014. Monthly Labor Review, 128(11), November, 70-101.

10. John-Charles, G. \& Walstrom, K. (2000). Influencing african americans' decisions to select an information technology major. Journal of Computer Information Systems, 41(1), 56-60.

11. Lowe, D.R. \& Simons, K. (1997). Factors influencing choice of business majors -- some additional evidence: a research note. Accounting Education, 6(1), 39-45.

12. Noland, T., Case, T., Francisco, W., \& Kelly, J. (2003) An analysis of academic major selection factors: A comparison of information systems and accounting students. Proceedings of the $18^{\text {th }}$ Annual Conference of the International Academy for Information Management, 18, 150-156.

13. Simons, K.A., Lowe, D.R. \& Stout, D.E. (2003). Comprehensive literature review: factors influencing choice of accounting as a major. Proceedings of the 2003 Academy of Business Education Conference. 